\title{
Program Pembiayaan Lembaga Keuangan Mikro Syariah (LKMS) dalam Peningkatan Kesejahteraan Pelaku Usaha Mikro (Studi Kasus BMT Baitul Karim Bekasi)
}

\section{Financing Program in Microfinance Institution (LKMS) of Welfare Enhancing for Micro Business Enterprises (Study Case in BMT Baitul Karim Bekasi)}

\author{
Widya Gina ${ }^{1}$, Jaenal Effendi ${ }^{2}$ \\ ${ }^{1}$ Institut Pertanian Bogor, widyagina@yahoo.com \\ ${ }^{2}$ Dosen Institut Pertanian Bogor, jaenfendi@gmail.com
}

\begin{abstract}
The role of micro business enterprises in employment is quite large, namely $99.9 \%$ of the total workforce in Indonesia. This suggests that micro businesses have a great opportunity in economic development and increased prosperity. This is not in accordance with the improvement of social welfare of the poor because of the high of the poor up to $10.96 \%$ of the total population. The limited capital on micro businesses is an obstacle that is difficult to be avoided. In this case, the financing provided by the BMT is crucial for micro enterprises in accessing capital. The purpose of this study is to analyze the effect of the financing program in increasing income and welfare of micro businesses. The method used in this research is the method of Ordinary Least Square (OLS and logistics method. Significant variables that positively affect the revenue are captured financing of respondents, the number of family members whose income, education, and ethical and moral variables. The variables that positively and significantly affect the welfare are the length of time member, meal expenses, average income, and financing that are taken by respondents.
\end{abstract}

Keywords: Finance, Methods of Logistics, Micro enterprise, Welfare

\begin{abstract}
Abstrak. Peran usaha mikro dalam penyerapan tenaga kerja sangat besar yaitu 99.9\% dari total tenaga kerja di Indonesia. Hal ini menunjukkan bahwa usaha mikro memiliki peluang besar dalam pembangunan ekonomi dan peningkatan kesejahteraan. Hal ini tidak sesuai dengan peningkatan kesejahteraan masyarakat karena tingginya masyarakat miskin yaitu sebesar $10,96 \%$ dari total penduduk. Terbatasnya modal pada pelaku usaha mikro menjadi kendala yang sulit untuk dihindari. Dalam hal ini, pembiayan yang diberikan oleh BMT menjadi penting bagi usaha mikro dalam mengakses permodalan. Tujuan dari penelitian ini adalah menganalisis pengaruh program pembiayaan dalam peningkatan pendapatan dan kesejahteraan pelaku usaha mikro. Metode yang digunakan dalam penelitian ini yaitu metode Ordinary Least Square (OLS) dan metode logistik. Variabel yang secara positif signifikan memengaruhi pendapatan adalah pembiayaan yang diambil responden, jumlah anggota keluarga yang berpenghasilan, pendidikan, dan variabel etika dan moral. Variabel yang secara positif dan signifikan memengaruhi kesejahteraan yaitu lamanya menjadi anggota, pengeluaran makan, pendapatan rata-rata, dan pembiayaan yang diambil responden.
\end{abstract}

Kata Kunci: Kesejahteraan, Metode Logistik, Pembiayaan, Usaha Mikro

\section{Pendahuluan}

Usaha Mikro, kecil dan Menengah (UMKM) mendominasi usaha di kalangan masyarakat. Pada tahun 2012, kontribusi UMKM dalam menyerap tenaga kerja yaitu sebesar $97.16 \%$ dari total pekerja di Indonesia, dimana $90.12 \%$ dari jumlah tersebut adalah tenaga kerja pada usaha mikro. Persentasi usaha mikro terbesar berada pada industri makanan dan disusul pada urutan kedua pada industri kayu, barang dari kayu dan gabus, (tidak termasuk furnitur), barang anyaman dari rotan, bambu, dan sejenisnya. Usaha mikro yang berada pada industri makanan memberikan kontribusi sebesar $34.31 \%$ pada tahun 2012 dan meningkat menjadi 58.19\% pada tahun 2013 yang menunjukkan persentase angka yang besar sebagai sumber pendapatan masyarakat (BPS 2013).

Seperti ditunjukkan pada Tabel 1, provinsi Jawa Barat menduduki peringkat ke empat tertinggi di Pulau Jawa dengan penduduk miskin desa dan kota yang menyumbang $9.18 \%$ dari total penduduk miskin di Indonesia pada periode September 2014 (BPS 2014). 
Tabel 1 Jumlah dan persentase penduduk miskin Pulau Jawa periode September 2014

\begin{tabular}{lrrrrrr}
\hline & \multicolumn{3}{c}{ Jumlah Penduduk Miskin (000) } & \multicolumn{3}{c}{ Persentase Penduduk Miskin (\%) } \\
\cline { 2 - 7 } & \multicolumn{1}{c}{ Kota } & \multicolumn{1}{c}{ Desa } & Kota+Desa & \multicolumn{1}{c}{ Kota } & Desa & Kota+Desa \\
\hline DKI & 412.79 & 0.00 & 412.79 & 4.09 & 0.00 & 4.09 \\
Jakarta & & & & & & \\
Jawa Barat & 2554.06 & 1684.90 & 4238.96 & 8.32 & 10.88 & 9.18 \\
Banten & 381.18 & 268.01 & 649.19 & 4.74 & 7.18 & 5.51 \\
Jawa & 1771.53 & 2790.29 & 4561.83 & 11.50 & 15.35 & 13.58 \\
Tengah & & & & & & \\
DI & 324.43 & 208.15 & 532.59 & 13.36 & 16.88 & 14.55 \\
Yogyakarta & & & & & & \\
Jawa & 1531.89 & 3216.53 & 4748.42 & 8.30 & 15.92 & 12.28 \\
Timur & & & & &
\end{tabular}

Sumber: Badan Pusat Statistik (2014)

Banyaknya pelaku usaha mikro yang menyerap jumlah tenaga kerja yang besar merupakan peluang yang besar dalam pembangunan ekonomi dan upaya peningkatan kesejahteraan. Namun, terbatasnya modal dan pendidikan pada pelaku usaha mikro menjadi kendala yang sulit untuk dihindari. Padahal, jika kita fokus terhadap pelaku usaha mikro yang menyerap hampir 110.8 juta tenaga kerja, sebanyak 97.16\% berada pada sektor UMKM, dimana $90.12 \%$ tenaga kerja diantaranya adalah usaha mikro, 4.09\% adalah usaha kecil, 2.94\% adalah usaha besar dan 2.84\% adalah usaha besar (Depkop 2012). Upaya pengentasan kemiskinan dapat dicapai dengan memberikan modal pada pelaku usaha mikro. Pelaku usaha mikro yang mendapatkan pembiayaan dapat meningkatkan produksi yang berimplikasi pada peningkatan pendapatan masyarakat. Pemberian pembiayaan pada pelaku usaha mikro yang dinilai tidak bankable dapat meningkatkan usaha dan taraf hidupnya. Namun, tidak banyak yang peduli dengan usaha mikro karena dinilai tidak bankable dan sulit untuk mengebangkan usaha atau masih banyak menilai bahwa usaha mikro merupakan usaha yang labil. Sehingga, lembaga keuangan formal seperti perbankan sulit memberikan pembiayaan pada pelaku usaha mikro karena dinilai berisiko dan jumlah pembiayaan yang tergolong kecil. Hal itu disebabkan karena sebagian besar usaha mikro berdiri kurang dari satu tahun yang apabila melihat usaha tersebut masih labil. Kurangnya pendidikan pada pelaku usaha menyebabkan kurangnya kepercayaan lembaga keuangan formal seperti bank untuk memberikan pembiayaan yang dikhawatirkan pelaku usaha tersebut tidak dapat mengelola dana pinjaman dengan baik, sehingga adanya kendala kredit macet.

Kehadiran BMT di tengah-tengah masyarakat sangat membantu para pelaku usaha mikro. Dengan keberadaan BMT, para pelaku usaha mikro yang disebut-sebut tidak bankable ini dapat mengakses permodalan dengan mudah tanpa adanya tingkat suku bunga yang dikhawatirkan dapat menambah beban peminjam dana. BMT berfungsi tidak hanya sebagai lembaga bisnis yang hanya mengambil profit, melainkan juga sebagai lembaga sosial, yaitu menghimpun tabungan haji, tabungan umrah, tabungan qurban. Di sisi lain, BMT juga sebagai lembaga bisnis yang berfungsi sebagai lembaga keuangan bagi pelaku UMKM dengan melakukan kegiatan simpan-pinjam dengan basis syariah, yaitu sistem bagi hasil. Dengan sistem bagi hasil ini, tidak ada tingkat bunga seperti yang diberikan oleh lembaga keuangan konvensional. Sehingga, keuntungan dan kerugian ditanggung bersama oleh pihak pemberi pinjaman dan penerima pinjaman.

Pemberian pembiayaan yang mudah bagi pelaku usaha mikro merupakan salah satu upaya dari lembaga keuangan mikro syariah untuk meningkatkan kesejahteraan masyarakat. Salah satu faktor yang selama ini menjadi persoalan klasik adalah terbatasnya akses permodalan untuk pelaku usaha mikro. Kendala permodalan menjadi penyebab sulitnya usaha mikro untuk meningkatkan produktivitas. Biasanya modal usaha mikro hanya bergantung pada modal sendiri dan atau keluarga. Adapun program pembiayaan pada usaha mikro dinilai sebagai upaya pemerintah dalam mengentaskan kemiskinan. Pembiayaan atau kredit mikro dalam konvensional sudah diakui dunia 
sebagai upaya dalam meningkatkan kesejahteraan. Dengan adanya akses modal, pelaku usaha mikro keluar dari gerbang kesulitan dalam upaya peningkatan aktivitas produksi dan dengan meningkatnya aktivitas produksi, seseorang dapat meningkatkan pendapatannya sehingga dapat meningkatkan kesejahteraannya (Bashir dan Rashidah, 2014).

Berdasarkan penjelas di atas, tujuan dari penelitian yaitu:

1. Menganalisis pengaruh dari pembiayaan Lembaga Keuangan Mikro Syariah terhadap peningkatan pendapatan pelaku usaha mikro

2. Menganalisis pengaruh pembiayaan Lembaga Keuangan Mikro Syariah terhadap kesejahteraan pelaku usaha mikro

\section{Tinjauan Pustaka}

\subsection{Lembaga Keuangan Mikro Syariah}

Menurut Undang-Undang Nomor 1 Tahun 2013, lembaga keuangan mikro yang selanjutnya disingkat dengan LKM adalah lembaga keuangan yang khusus didirikan untuk memberikan jasa pengembangan usaha dan pemberdayaan masyarakat, baik melalui pinjaman atau pembiayaan dalam usaha skala mikro kepada anggota dan masyarakat, pengelolaan simpanan, maupun pemberian jasa konsultasi pengembangan usaha yang tidak semata-mata mencari keuntungan.

Menurut Khodijah et al. (2013) lembaga keuangan mikro Islam yaitu lembaga yang memperkenalkan sebagai pilihan untuk masyarakat yang memiliki pengahasilan yang rendah untuk mendapatkan pembiayaan agar dapat meningkatkan taraf hidup dan keluar dari kemiskinan. Sehingga, definisi yang dijelaskan tersebut mengacu pada bagaimana suatu lembaga keuangan syariah dapat bermanfaat bagi nasabah sebagai pelaku usaha mikro sehingga ia dapat meningkatkan taraf kehidupannya dan keluar dari kemiskinan yang selama ini usaha mikro dikenal sulit mendapatkan pembiayaan dari bank dan lembaga keungan mikro yang siap dan peduli pada usaha-usaha mikro di masyarakat.

\subsection{Pengertian Usaha Mikro}

Menurut Undang-Undang Nomor 20 Tahun 2008, usaha mikro adalah usaha usaha produktif milik perseorangan yang memenuhi kriteria usaha mikro sebagaimana yang diatur dalam undang-undang ini. Aset yang dimiliki usaha mikro tidak lebih dari Rp 50000000.00 dengan omzet yang tidak lebih dari Rp 300000000.00 per tahun. Menurut Keputusan Menteri Keuangan No.40/KMK.06/2003 tanggal 29 Januari 2013, usaha mikro usaha produktif milik keluarga atau perorangan Warga Negara Indonesia dan memiliki hasil penjualan paling banyak Rp 100000000.00 per tahun. Usaha mikro dapat mengajukan kredit kepada bank paling banyak Rp 50000000.00.

Tabel 2 Kriteria usaha mikro, kecil, dan menengah menurut UU No.20 Tahun 2008

\begin{tabular}{clll}
\hline \multirow{2}{*}{ No. } & \multicolumn{1}{c}{ Uraian } & \multicolumn{1}{c}{ Kriteria } \\
\cline { 3 - 4 } & & \multicolumn{1}{c}{ Asset } & \multicolumn{1}{c}{ Omzet } \\
\hline 1. & Usaha Mikro & Maks. 50 Juta & Maks. 300 Juta \\
2. & Usaha Kecil & 50 Juta - 500 Juta & 300 Juta -2.5 Miliar \\
3. & Usaha Menengah & 500 Juta -10 Miliar & 2.5 Miliar - 50 Miliar \\
\hline
\end{tabular}

Sumber: Kementerian Koperasi dan UMKM (2012)

Menurut Tambunan (2009), usaha mikro mencakup aspek formalitas, organisasi dan manajemen, sifat dan kesempatan kerja, dan lain-lainnya secara detil dijelaskan pada Tabel 3. Mayoritas usaha mikro berada pada sektor informal dan tidak terdaftar. Hal tersebut menyebabkan kurangnya kepercayaan lembaga keuangan formal dalam memberikan permodalan (Fahrudin 2012). Karakteristik lain yang 
menonjol di antaranya yaitu pendidikan yang rendah oleh pelaku usaha mikro dan biasanya hasil produksi ditujukan untuk kelompok berpendapatan rendah.

Tabel 3 Karakteristik Usaha Mikro

\begin{tabular}{|c|c|c|}
\hline No. & Aspek & Usaha Mikro \\
\hline 1. & Formalitas & $\begin{array}{l}\text { Beroperasi di sektor informal; usaha tidak } \\
\text { terdaftar; tidak/jarang bayar pajak. }\end{array}$ \\
\hline 2 . & Organisasi dan manajemen & $\begin{array}{l}\text { Dijalankan oleh pemilik; tidak menerapkan } \\
\text { pembagian tenaga kerja internal, manajemen dan } \\
\text { struktur organisasi formal, sistem pembukuan } \\
\text { formal. }\end{array}$ \\
\hline 3. & Sifat & $\begin{array}{l}\text { Kebanyakan menggunakan anggota-anggota } \\
\text { keluarga tidak dibayar. }\end{array}$ \\
\hline 4. & $\begin{array}{l}\text { Pola/sifat dari proses } \\
\text { produksi }\end{array}$ & $\begin{array}{l}\text { Derajat mekanisasi sangat rendah/umumnya } \\
\text { manual; tingkat teknologi sangat rendah. }\end{array}$ \\
\hline 5. & pasar & $\begin{array}{l}\text { Umumnya menjual ke pasar lokal untuk } \\
\text { kelompok berpendapatan rendah. }\end{array}$ \\
\hline 6. & $\begin{array}{l}\text { Profil ekonomi dan } \\
\text { dari pemilik usaha }\end{array}$ & $\begin{array}{l}\text { Pendidikan rendah dan dari rumah tangga } \\
\text { miskin; motivasi utama adalah survival. }\end{array}$ \\
\hline 7. & $\begin{array}{l}\text { Sumber-sumber dari bahan } \\
\text { baku dan modal }\end{array}$ & $\begin{array}{l}\text { Kebanyakan pakai bahan baku lokal dan uang } \\
\text { sendiri. }\end{array}$ \\
\hline 8. & $\begin{array}{l}\text { Hubungan-hubungan } \\
\text { eksternal }\end{array}$ & $\begin{array}{l}\text { Kebanyakan tidak punya akses ke program- } \\
\text { program pemerintah dan tidak punya hubungan- } \\
\text { hubungan bisnis dengan usaha besar. }\end{array}$ \\
\hline 9. & $\mathrm{Wa}$ & $\begin{array}{l}\text { Rasio dari wanita terhadap pria sebagai } \\
\text { pengusaha sangat tinggi. }\end{array}$ \\
\hline
\end{tabular}

\subsection{Pembiayaan Syariah}

Menurut Zaman (1999), pembiayaan mikro berkontribusi untuk mengurangi sejumlah faktor yang menyebabkan kemiskinan, dimana masyarakat miskin dapat memulai untuk menghasilkan pendapatan. Pembiayaan dapat memutus visious cycle UMKM yang menyebabkan pelaku usaha mikro berpendapatan rendah. Pembiayaan yang diberikan oleh lembaga informal seperi BMT merupakan alternatif bagi usaha mikro untuk mendapatkan modal dalam mengembangkan usahanya, sehingga dengan adanya tambahan modal pelaku usaha mikro dapat meningkatkan produksi.

\subsection{Tujuan dan Fungsi Kesejahteraan Sosial}

Fahrudin (2012) mengemukakan tujuan dari kesejahteraan sosial yaitu:

1. Untuk mencapai kehidupan yang sejahtera dalam arti tercapainya standar kehidupan pokok seperti sandang, perumahan, pangan, kesehatan, dan relasi-relasi sosial yang harmonis dengan lingkungannya.

2. Untuk mencapau penyesusaian diri yang baik khususnya dengan masyarakat di lingkungannya, misalnya dengan menggali sumber-sumber, meningkatkan, dan mengembangkan taraf hidup yang memuaskan.

Adapun Schneiderman (1972) mengemukakan tiga tujuan utama dari sistem kesejahteraan sosial yang mencerminkan kesejahteraan sosial sampai tingkat tertentu, yaitu:

1. Pemeliharaan Sistem

Pemeliharaan dan menjaga keseimbangan atau kelangsungan keberadaan nilai-nilai dan normanorma sosial serta aturan-aturan kemasyarakatan dalam masyarakat, termasuk hal-hal yang bertalian dengan definisi makna dan tujuan hidup; motivasi bagi kelangsungan hidup orang seorang dan kelompok; norma-norma yang menyangkut pelaksanaan peranan anak-anak, remaja, 
dewasa, dan orang tua, dan peranan pria dan wanita; norma-norma yang berhubungan dengan penyelesaian konflik dalam masyarakat, dan lain-lain.

2. Pengawasan Sistem

Melakukan pengawasan secara efektif terhadap perilaku yang tidak sesuai atau menyimpang dari nilai-nilai sosial. Kegiatan-kegiatann kesejahteraan sosial untuk mencapai tujuan semacam itu meliputi; mengintensifikasikan fungsi-fungsi pemeliharaan berupa kompensansi, sosialisasi, peningkatan kemampuan menjangkau fasilitas-fasilitas yang ada bagi golongan masyarakat yang memperlihatkan penyimpangan tingkah laku.

3. Perubahan Sistem

Mengadakan perubahan ke arah berkembangnya suatu sistem yang lebih efektif bagi anggota masyarakat (Effendi, 1982; Zastrow, 1982). Dalam mengadakan perubahan itu, sistem kesejahteraan sosial merupakan instrumen untuk menyisihkan hambatan-hambatan terhadap partisipasi sepenuhnya dan adil bagi anggota masyarakat dalam pengambilan keputusan; pembagian sumber-sumber secara lebih pantas dan adil; dan terhadap penggunaan struktur kesempatan yang tersedia secara adil pula.

\subsection{Penelitian Terdahulu}

Rahman (2010) menganalisis faktor-faktor yang memengaruhi peningkatan pendapatan dan kesejahteraan pelaku usaha mikro di bawah program pembiayaan pada 1.020 responden di Bangladesh sebagai sampelnya. Penelitian tersebut menunjukkan bahwa beberapa variabel seperti pembiayaan yang diambil nasabah, jumlah anggota keluarga yang menghasilkan pendapatan, usia peminjam, etika dan moral nasabah berpengaruh positif dan signifikan terhadap peningkatan pendapatan usaha mikro. Selain itu, variabel yang memengaruhi kesejahteraan nasabah di bawah program pembiayaan, yaitu: lamanya menjadi anggota, jumlah anggota keluarga yang memiliki pendapatan, pengeluaran makan dibandingkan dengan total pengeluaran, pengeluaran untuk kesehatan, dan etika dan moral nasabah berpengaruh positif dan signifikan. kesimpulan penelitian ini yaitu bahwa program pembiayaan merupakan salah satu program pengentasan kemiskinan yang diimplementasikan di seluruh dunia. Program pembiayaan mikro meningkatkan sosioekonomi secara keseluruhan yang memainkan peran penting dalam pengentasan kemiskinan.

Penelitian yang dilakukan oleh Faisal (2013) yang menganalisis aplikasi pembiayaan qardh dan kaitannya dengan kesejahteraan sosial dalam sistem ketatanegaraan bagi pencapaian tujuan perbankan syariah menjelaskan bahwa ada korelasi yang sangat erat antara pembiayaan qardh dengan fungsi kesejahteraan sosial. Hal tersebut diwujudkan dalam produk perbankan seperti dana talangan haji, usaha mikro, kecil dan menengah (UMKM) dan kegiatan sosial lainnya.

Dusuki (2007) dalam penelitiannya Banking for the Poor: The Role of Islamic Banking in Microfinance Initiative menjelaskan bahwa keuangan mikro diakui secara luas sebagai pendekatan yang inovatif dalam pengentasan kemiskinan. Dengan berbagai mekanisme yang dapat membantu masyarakat miskin mendapatkan akses pembiayaan dari produk dan jasa keuangan perbankan syariah. Studi ini juga menjelaskan bagaimana keuangan mikro dapat berpartisipasi dalam pendanaan usaha mikro masyarakat miskin.

\section{Metode Penelitian}

\subsection{Jenis dan Sumber Data}

Penelitian ini menggunakan sumber data primer dan data sekunder. Sumber data primer dilakukan langsung dengan metode wawancara pada 45 pelaku usaha mikro yang melakukan pembiayaan di BMT Baitul Karim Bekasi staf manajemen BMT, sedangkan data sekunder diperoleh dari laporan bulanan dan tahunan BMT, Kementerian Koperasi dan UMKM, buku, jurnal, skripsi, dan thesis yang mendukung dalam pembuatan skripsi ini. 


\subsection{Lokasi Penelitian}

Penelitian ini dilakukan di Baitul Mal wa Tamwil (BMT) Baitul Karim Bekasi, Provinsi Jawa Barat. Penelitian dan pengambilan data dilakukan pada minggu ketiga bulan Januari 2015 sampai dengan minggu keempat bulan Februari 2015.

\subsection{Metode Analisis Data}

Penelitian ini menggunakan data kualitatif dan data kuantitatif. Data diperoleh dari hasil wawancara yang akan diolah dengan menggunakan analisis data kuantitatif sehingga data dapat diinterprestasikan dengan baik melalui model yang digunakan. Data kualitatif diperoleh untuk mendukung hasil penelitian dengan pendekatan analisis deskriptif, sedangkan data kuantitaif digunakan untuk memberikan nilai sehingga analisis data lebih tepat menggunakan analisis logistik dan model Ordinary Least Square (OLS).

\subsection{Model Penelitian}

Penelitian ini menggunakan dua model, yaitu model Ordinary Least Square (OLS) dengan variabel dependen pendapatan rata-rata keluarga dan model logistik.dengan variabel dependen adalah kesejahteraan berdasarkan opini nasbah.

Model 1 digunakan untuk menganalisis faktor-faktor yang memengaruhi pendapataan keluarga:

$\log Y=\alpha_{0}+b_{i} \log X_{1}+b_{i} \log X_{2}+b_{i} D_{1}+b_{i} D_{2}+b_{i} D_{3}+b_{i} D_{4}+e_{i}$

Dimana,

$\mathrm{Y}=$ Rata-rata pendapatan rumah tangga

$\mathrm{X}_{1}=$ Pembiayaan yang diambil peminjam

$\mathrm{X}_{2}=$ Jumlah anggota keluarga yang menghasilkan pendapatan

$\mathrm{D}_{1}=$ Dummy Usia peminjam (Usia di atas 40 tahun diberi nilai 1, dan lainnya 0 )

$\mathrm{D}_{2}=$ Dummy Jarak cabang dengan rumah peminjam (Jarak di atas $10 \mathrm{~km}$ diberi nilai 1 dan lainnya $0)$

$\mathrm{D}_{3}=$ Dummy Pendidikan peminjam (Pendidikan di atas 6 tahun diberi nilai 1 dan lainnya 0 )

$\mathrm{D}_{4}=$ Dummy Etika dan moral peminjam

Model 2 digunakan untuk menganalisis faktor-faktor yang memengaruhi kesejahteraan berdasarkan opini nasabah:

$$
\operatorname{Ln}\left[\frac{P_{1}}{1-P_{1}}\right]=b_{i}+b_{i} X_{1}+b_{i} X_{2}+b_{i} X_{3}+b_{i} X_{4}+b_{i} X_{5}+e_{i} \ldots
$$

Dimana,

$\mathrm{P}_{\mathrm{i}} \quad=$ Probabilitas bahwa peminjam sejahtera berdasarkan opini nasabah

1- $\mathrm{P}_{\mathrm{i}} \quad=$ Probabilitas bahwa peminjam tidak sejahtera berdasarkan opini nasabah

$\mathrm{X}_{1} \quad=$ Lamanya menjadi anggota (tahun)

$\mathrm{X}_{2} \quad=$ Pengeluaran untuk makan dari total pendapatan (\%)

$\mathrm{X}_{3}=$ Pengeluaran untuk perawatan kesehatan (rupiah)

$\mathrm{X}_{4} \quad=$ Pendapatan rata-rata keluarga (rupiah)

$\mathrm{X}_{5} \quad=$ Pembiayaan yang diambil peminjam (rupiah)

$b_{i} \quad=$ Konstanta

$e_{i} \quad=$ Eror

$b_{1}, b_{2}, b_{3}, \ldots, b_{5}=$ Koefisien estimasi 


\section{Hasil Penelitian}

\subsection{Persentase Peningkatan Pendapatan Responden Setelah Pembiayaan}

Pembiayaan merupakan salah satu cara dalam mengatasi akses permodalan pada usaha mikro yang mengalami keterbatasan akses permodalan pada lembaga keuangan formal seperti perbankan. Dengan adanya pembiayaan yang diberikan BMT kepada pelaku usaha mikro, pelaku usaha dapat lebih produktif dalam menghasilkan pendapatan. Dalam penelitian ini, pembiayaan yang diambil oleh responden berupa murabahah dengan akad jual-beli.

Tabel 4 Pendapatan rata-rata setelah melakukan pembiayaan

\begin{tabular}{|c|c|c|}
\hline Pendapatan Rata-Rata (rupiah) & Jumlah (orang) & Persentase $(\%)$ \\
\hline $1.000 .000-5.000 .000$ & 29 & 64.44 \\
\hline $5.000 .000-10.000 .000$ & 13 & 28.89 \\
\hline$>10.000 .000$ & 3 & 6.67 \\
\hline Total & 45 & 100 \\
\hline
\end{tabular}

Berdasarkan Tabel 4 pendapatan rata-rata setelah melakukan pembiayaan. Responden yang memiliki pendapatan antara Rp 1000000.00 - Rp 5000000.00 sebanyak 29 orang atau sebesar $64.44 \%$ dari total responden penelitian. sedangakan responden yang memiliki pendapatan antara Rp 5000000.00 - Rp 10000000.00 sebanyak 13 orang atau sebesar 28.89\% dari total responden dan sebesar 3\% memiliki pendapatan di atas Rp 10000000.00 per bulan. Hal ini menunjukkan bahwa pembiayaan sangat berpengaruh pada pendapatan responden yang diteliti. Seperti yang dijelaskan pada Tabel 5 bahwa hanya beberapa responden yang menyatakan bahwa pendapatannya cenderung turun setelah melakukan pembiayaan. Hal ini disebabkan karena faktor eksternal seperti keadaan bulan Ramadhan sehingga usaha warung kelontongannya turun drastis, pembatasan permintaan galon air pada pedagang eceran, dan pembiayaan yang dilakukan saat usaha pailit.

Tabel 5 Pertumbuhan pendapatan setelah melakukan pembiayaan

\begin{tabular}{|c|c|c|}
\hline Pertumbuhan Pendapatan & Jumlah (orang) & Persentase $(\%)$ \\
\hline Naik & 42 & 93.33 \\
\hline Turun & 3 & 6.67 \\
\hline Total & 45 & 100 \\
\hline
\end{tabular}

\subsection{Persentase Peningkatan Keuntungan Usaha Mikro Setelah Pembiayaan}

Tabel 6 menunjukkan keuntungan yang didapat dari usaha mikro responden. Sebagian besar responden mendapatkan keuntungan dari hasil usahanya antara rentang Rp 1000000.00 - Rp 5000 000.00 per bulan yaitu sebanyak 37 orang atau sebesar $82.23 \%$ dari total responden penelitian.ratarata keuntungan yang didapat responden adalah sekitar empat juta rupiah setiap bulannya dengan standar deviasi sebesar

Tabel 6 Keuntungan usaha mikro responden per bulan

\begin{tabular}{|c|c|c|}
\hline Keuntungan Usaha (rupiah) & Jumlah (orang) & Persentase $(\%)$ \\
\hline$<1.000 .000$ & 2 & 4.44 \\
\hline $1.000 .000-5.000 .000$ & 37 & 82.23 \\
\hline $5.000 .000-10.000 .000$ & 4 & 8.89 \\
\hline$>10.000 .000$ & 2 & 4.44 \\
\hline Total & 45 & 100 \\
\hline
\end{tabular}




\subsection{Dampak Pembiayaan Mikro Syariah terhadap Pendapatan Keluarga Pelaku Usaha Mikro dengan Orinary Least Square (OLS)}

Salah satu masalah yang mendasar bagi usaha mikro adalah permodalan. Usaha mikro memiliki akses yang terbatas pada lembaga keuangan formal dalam hal mendapatkan pembiayaan usaha. Dalam penelitian ini, dijelaskan bahwa pembiayaan memiliki hubungan positif signifikan terhadap peningkatan pendapatan pelaku usaha mikro. Meningkatnya pendapatan dikerenakan adanya tambahan modal pada usaha dalam mengembangkan usahanya.

Pada hasil pengolahan data menggunakan metode Ordinary Least Square (OLS) yang telah dilakukan, didapatkan $R$-square dari persamaan sebesar 0.935 yang berarti bahwa $93.5 \%$ keragaman nilai pendapatan rata-rata dapat dijelaskan oleh variabel-variabel penjelas dan sisanya dijelaskan oleh variabel lain di luar model. Model OLS yang digunakan sudah bebas dari pelanggaran-pelanggaran asumsi. Hal tersebut dikarenakan pada model sudah dilakukan uji asumsi klasik seperti uji normalitas, uji homogenitas, uji autokorelasi, dan uji multikolinearitas. Uji normalitas dilihat dengan one-sample kolmogorov-smirnov test, uji homogenitas dilihat dengan uji Breusch-Pagan-Godfrey, uji autokerelasi dilihat dari nilai Durbin-Watson, dan uji multikolineritas dilihat dari nilai VIF yang tidak lebih dari 10. Variabel signifikan pada taraf 5\% yaitu pembiayaan, anggota keluarga yang memiliki penghasilan, dummy pendidikan, dan dummy etika dan moral.

Table 7 Faktor-faktor yang memengaruhi pendapatan keluarga

\begin{tabular}{lrrr}
\hline \multicolumn{1}{c}{ Variable } & Coefficients & \multicolumn{1}{c}{ t-value } & \multicolumn{2}{c}{ Sig. } \\
\hline Constant & 4.223 & 13.458 & 0.000 \\
Log Pembiayaan & 0.317 & 6.934 & $0.000^{*}$ \\
Dummy Usia & -0.002 & -0.078 & 0.938 \\
Log Anggota Keluarga & 0.295 & 4.538 & $0.000^{*}$ \\
Berpenghasilan & 0.000064 & 0.054 & 0.957 \\
Dummy Jarak & 0.346 & 8.719 & $0.000^{*}$ \\
Dummy Pendidikan & 0.072 & 3.223 & $0.003^{*}$ \\
Dummy Etika dan Moral & & & \\
\hline R-Squared: $93.5 \%$ & &
\end{tabular}

Besarnya pembiayaan berpengaruh positif signifikan terhadap pendapatan yang diperoleh keluarga dengan nilai koefisien sebesar 0.317 pada taraf 5\%. Artinya, pembiayaan berpengaruh nyata pada pendapatan keluarga. Nilai koefisien sebesar 0.317 menunjukkan bahwa kenaikan pembiayaan sebesar $1 \%$ akan mengakibatkan kenaikan pendapatan rata-rata sebesar $0.317 \%$, ceteris paribus. Hal ini menjelaskan bahwa pembiayaan memiliki dampak positif pada pendapatan rata-rata usaha, sehingga BMT memainkan peran yang sangat penting bagi keberlangsungan perkembangan usaha mikro yang memiliki keterbatasan akses permodalan sebagai unit usaha yang dinilai tidak bankable. Hal ini didukung oleh Rahman (2010) pada jurnal internasional yang menyatakan bahwa pembiayaan meningkatkan pendapatan keluarga. Hasil wawancara di lapangan juga menjelaskan bahwa sekitar 93\% dari total responden menyatakan bahwa pendapatan rata-rata meningkat setelah melakukan pembiayaan.

Banyaknya jumlah anggota keluarga yang menghasilkan pendapatan berpengaruh positif signifikan terhadap pendapatan yang diperoleh pelaku usaha mikro dengan nilai koefisien sebesar 0.295 pada taraf 5\%. Artinya, jumlah anggota keluarga yang memiliki penghasilan berpengaruh nyata pada pendapatan keluarga. Nilai koefisien sebesar 0.295 menunjukkan bahwa kenaikan jumlah anggota keluarga sebesar $1 \%$ akan mengakibatkan kenaikan pendapatan rata-rata sebesar $0.295 \%$, ceteris paribus. Dari hasil penelitian di lapangan, bahwa semakin banyak anggota keluarga yang memiliki pedapatan, maka anggota keluarga tersebut akan memberikan share pada pelaku usaha mikro sehingga adanya tambahan pendapatan yang diterima di luar pendapatan usaha yang dijalankan. 
Hasil penelitian menunjukkan bahwa pendidikan berpengaruh positif terhadap pendapatan rata-rata yang diperoleh pelaku usaha mikro dengan nilai koefisien sebesar 0.346 pada taraf 5\%. Artinya, anggota yang memiliki pendidikan lebih tinggi (dalam hal ini lulusan SMP, SMA, dan PT) mendapatkan pendapatan rata-rata yang lebih tinggi dibandingkan dengan anggota yang memiliki pendidikan yang rendah (dalam hal ini lulusan SD), ceteris paribus. Hal ini menjelaskan bahwa semakin lama pendidikan responden, maka akan semakin baik dalam mendapatkan pendapatan keluarga. Pendidikan yang semakin tinggi membuat seseorang lebih mengerti untuk melakukan hal yang produktif dalam melakukan aktivitasnya.

Dummy etika dan moral nasabah berpenaruh positif signifikan terhadap pendapatan rata-rata yang diperoleh oleh pelaku usaha mikro dengan koefisien sebesar 0.072 pada taraf $5 \%$. Artinya, anggota yang bermoral dan beretika mendapatkan pendapatan rata-rata yang lebih tinggi dibandingkan dengan anggota yang dinilai tidak memiliki moral dan etika, ceteris paribus. Moral dan etika nasabah berpengaruh secara positif dikarenakan dengan memiliki moral dan etika, nasabah dapat memilih untuk apa saja pendapatannya dialokasikan. Nasabah yang memiliki moral dan etika dinilai dapat mengalokasikan pendapatannya pada aktivitas produktif, sehingga dapat berimplikasi pada peningkatan pendapatan rata-rata (Rahman 2010).

\subsection{Faktor-Faktor yang Memengaruhi Kesejahteran dengan Model Logistik}

Model logit yang digunakan dalam penelitian yaitu untuk melihat faktor-faktor yang memengaruhi kesejahteraan nasabah yang melakukan pembiayaan pada BMT. Kesejahteraan dinilai berdasarkan opini nasabah yang telah mendapatkan pembiayaan, nilai 1 untuk nasabah yang mengaku dirinya sejahtera dan nilai 0 untuk nasabah yang mengaku dirinya tidak sejahtera. Model logit digunakan untuk mengetahui probabilitas apakah nasabah sejahtera berdasarkan pernyataan responden dapat dipengaruhi oleh variabel-variabel penjelasnya.

Tabel 8 Faktor-faktor yang memengaruhi kesejahteraan nasabah pembiayaan

\begin{tabular}{|c|c|c|c|c|c|c|}
\hline Variable & $B$ & $\begin{array}{l}\text { Std. } \\
\text { Error }\end{array}$ & $\begin{array}{c}\text { Wald } \\
\text { Statistic }\end{array}$ & $D f$ & Sig. & $\begin{array}{c}\text { Odds } \\
\text { Ratio } \\
\text { Exp }(B) \\
\end{array}$ \\
\hline Constant & $-8,399$ & 3,615 & 5,398 & 1 & 0,020 & 0,000 \\
\hline Lama Anggota & 0,169 & 0,083 & 4,149 & 1 & $0,042^{*}$ & 1,184 \\
\hline Pengeluaran Makan & 0,084 & 0,050 & 2,873 & 1 & $0,090 * *$ & 1,088 \\
\hline Pengeluaran Kesehatan & 0,000 & 0,000 & 1,976 & 1 & 0,160 & 1,000 \\
\hline Pendapatan & 1,076 & 0,436 & 6,079 & 1 & $0,014^{*}$ & 1,000 \\
\hline Pembiayaan & 0,000 & 0,000 & 5,023 & 1 & $0,025^{*}$ & 1,000 \\
\hline \multicolumn{7}{|l|}{ Cox and Snell R- } \\
\hline$-2 \log$ likelihood:28,384 & \multicolumn{6}{|c|}{ square: 0,382} \\
\hline Overall Accuracy: $82,2 \%$ & & & & & & \\
\hline
\end{tabular}

Hasil pendugaan model logit untuk faktor-faktor yang memengaruhi kesejahteraan nasabah yang telah melakukan pembiayaan di BMT menunjukkan tiga variabel yang signifikan pada taraf nyata $5 \%$, yaitu lama menjadi anggota, pendapatan rata-rata keluarga, dan pembiayaan yang diambil oleh responden. Sedangkan variabel yang signifikan pada taraf $10 \%$ yaitu pengeluaran makan keluarga.

Variabel lama menjadi anggota BMT memiliki nilai odds ratio sebesar 1.184 yang artinya peluang anggota yang lama 1.184 kali lebih sejahtera dibandingkan dengan anggota baru, ceteris paribus. Dalam hal ini, lama anggota berpengaruh positif pada opini sejahtera nasabah karena semakin lama seseorang menjadi anggota, semakin sering juga nasabah melakukan pembiayaan untuk usaha mikronya. Dengan semakin lama menjadi anggota juga membuat pengurus BMT lebih percaya pada 
nasabah sehingga dapat memberikan pembiayaan lebih sering dan dampaknya yaitu pada perkembangan usaha mikro itu sendiri.

Variabel pendapatan memiliki nilai odds ratio sebesar 2.932 yang artinya peluang anggota yang memiliki pendapatan lebih tinggi 2.932 lebih sejahtera dibandingkan dengan anggota yang memiliki pendapatan lebih rendah, ceteris paribus. Dalam hal ini, pendapatan berpengaruh positif terhadap kesejahteraan karena semakin tinggi pendapatan, maka pelaku usaha mikro dapat lebih memenuhi kebutuhan keluarga dan dapat dialokasikan lebih banyak pada aktivitas yang lebih produktif.

Variabel pembiayaan memiliki nilai odds ratio sebesar 1.000 yang artinya peluang anggota yang mendapatkan pembiayaan, baik tinggi maupun rendah memiliki peluang yang sama untuk sejahtera, ceteris paribus. Dalam hal ini, tentu saja pembiayaan memiliki pengaruh yang positif pada kesejahteraan karena semakin besar pembiayaan yang diambil semakin besar suntikan permodalan bagi usaha mikro dalam menjalankan usahanya sehingga dapat membuat usaha mikro lebih berkembang dan menghasilkan lebih banyak pendapatan dibandingkan dengan sebelum mendapatkan pembiayaan.

Variabel pengeluaran makan memiliki nilai odds ratio sebesar 1.088 yang artinya peluang anggota yang memiliki pengeluaran makan lebih tinggi 1.088 kali lebih sejahtera dibandingkan dengan anggota yang memiliki pengeluaran makan lebih rendah, ceteris paribus. Seseorang yang memiliki daya beli yang rendah akan mengeluarkan pengeluaran pada level yang lebih rendah, dan mereka yang menghabiskan lebih banyak pengeluaran untuk makan yang lebih berkualitas dikatakan dapat memperbaiki kehidupan sehingga lebih sejahtera (Rahman, 2010).

\section{Simpulan}

Berdasarkan hasil penelitian, maka diperoleh kesimpulan sebagai berikut:

1. Jumlah pembiayaan yang diambil responden berpengaruh positif dan signifikan terhadap peningkatan pendapatan pelaku usaha mikro dengan didukung oleh variabel-variabel lain seperti jumlah anggota keluarga yang memiliki penghasilan, tingkat pendidikan, dan variabel etka dan moral nasabah.

2. Jumlah pembiayaan yang diambil responden berpengaruh signifikan pada kesejahteraan berdasarkan opini responden dengan didukung oleh variabel lain seperti lamanya menjadi anggota BMT, pengeluaran makan, dan pendapatan responden.

\section{Daftar Pustaka}

Antonio MS. 2001. Bank Syariah dari Teori ke Praktik. Jakarta (ID): Gema Insani

Ariyanto DAN. 2011. Peranan Al-Mudharabah sebagai Salah Satu Produk Perbankan Syariah dalam Upaya Mengentaskan Kemiskinan di Indonesia. Jurnal Ekonomi dan Pendidikan. Volume 8 Nomor 2, November 2011

[BKKBN]. 2013. Usia Produktif dan Ketenagakerjaan. [internet]. [diunduh 2015 Maret 20]. Tersedia pada: http://www.bkkbn.go.id

[BPS] Badan Pusat Statitik. 2014. Tingkat Pertumbuhan Penduduk Miskin Periode 2013 - 2014. [internet]. [diunduh 2015 Januari 10]. Tersedia pada http://www.bps.go.id

[BPS] Badan Pusat Statitik. 2012. Tabel Perkembangan UMKM Periode 1997-2012. [internet]. [diunduh 2015 Januari 4]. Tersedia pada http://www.bps.go.id

[DEPKOP] Kementerian Koperasi dan UKM. 2012. Perkembangan Data Usaha Mikro, Kecil, dan Menengah (UMKM), dan Usaha Besar (UB) Tahun 2011-2012. [internet]. [diunduh 2014 Desember 3]. Tersedia pada: http://www.depkop.go.id.

[DEPKOP] Kementerian Koperasi dan UKM. 2012. Kriteria usaha mikro, kecil, dan menengah menurut UU No. 20 Tahun 2008 Tentang UMKM. [internet]. [diunduh 2014 September 2014]. Tersedia pada: http://www.depkop.go.id 
Dusuki AW. 2007. Banking for the Poor: The Role of Islamic Banking in Microfinance Initiatives. Proceedings of the 2nd Islamic Conference 2007 (iECONS2007)

Fahrudin A. 2012. Pengantar Kesejahteraan. Bandung: PT Rafika Aditama

Faisal. 2013. Aplikasi Pembiayaan Qardh dan Kaitannya dengan Kesejahteraan Sosial Dalam Sistem Ketatanegaraan Bagi Pencapaian Tujuan Perbankan Syariah. Jurnal Hukum Tata Negara. Vol.2 No.1 April 2013 hlm. 132-148

Firdaus M, Harmini, Farid. 2011. Aplikasi Metode Kuantitatif untuk Manajemen dan Bisnis. Bogor (ID): IPB Press

Hidayati N. 2014. Faktor-Faktor yang Memengaruhi Realisasi Pembiayaan Mikro Syariah dan Dampaknya terhadap Omzet Usaha Nasabah: Studi Kasus KJKS BMT UGT Sidogiri cabang Koja Jakarta [skripsi] . Bogor (ID): Institut Pertanian Bogor

Karim R, Shamsunnahar T, Manzur RF. 2012. Role of Micro-Credit in Poverty Alleviation of Rural Poor: Evidence fro Laxmipur District of Bangladesh. Volume-VII Number-02, July-December, 2012

Khadijah S, Saleh NEP, Kamarudin MF, Haryadi A. 2013. Sustainability of Islamic Micro Finance Institutions (IMFIs). Journal of Accounting and Finance. DOI. 10.13189/ujaf.2013.010205

Oktavi S. 2009. Analisis Faktor-Faktor yang Memengaruhi Pengambilan Pembiayaan dan Efektivitas Pembiayaan Usaha Kecil pada Lembaga Keuangan Mikro Syariah: Studi Kasus KJKS BMT Bina Umat Sejahtera. Bogor (ID). Institut Pertanian Bogor

Rahman MM. 2010. Islamic Micro-finance and Its Impact on Rural Poverty Alleviation. International Journal of Banking and Finance. Vol.7 Issue 1, article 7

Septiana RM. 2013. Analisis Dampak Pembiayaan Mikro Syariah terhadap Perkembangan Keuntungan UMKM di Kota Bogor [skripsi]. Bogor (ID): Insitut Pertanian Bogor

Soemitra A. 2009. Bank dan Lembaga Keungan Syariah. Jakarta: Kencana

Supriyanto. 2006. Pemberdayaan Usaha Mikro, Kecil, Menengah (UMKM) sebagai Salah Satu Upaya Pengentasan Kemiskinan. Jurnal Ekonomi dan Pendidikan. Volume 3 Nomor 1, April 2006

Tambunan T. 2009. UMKM di Indonesia. Bogor (ID): Ghalia Indonesia

[TNP2K] Tim Nasional Percepatan Penanggulangan Kemiskinan. 2012. Perkembangan Tingkat Kemiskinan Indonesia. [internet]. [diunduh 2014 September 9]. Tersedia pada: http://www.tnp2k.go.id

[TNP2K] Tim Nasional Percepatan Penanggulangan Kemiskinan. 2012. Program Kredit Usaha Rakyat (KUR). [internet]. [diunduh 2014 Januari 15]. Tersedia pada: http://www.tnp2k.go.id

Tsafe BM, Rahman RA. 2013. Effects of Spiritually on Board Performance in Malaysian Microfinance Firs. Middle-East Journalof Scientific Research 18 (5): 675-688, 2013

Tunas ANP._2014. Analisis Pengaruh Pembiayaan Syariah terhadap Perkembangan Usaha Mikro Kecil Menengah di Kota Depok [skripsi]. Bogor (ID): Institut Pertanian Bogor

Zaman H. 1999. Assessing the Poverty and Vulnerability Impact of Micro-Credit in Bangladesh: A case study of BRAC. Research Paper 2145 